\title{
STRATEGICKÉ RIADENIE LUUSKÝCH ZDROJOV V PODMIENKACH SLOVENSKEJ POŠTY
}

\author{
Kamila Jandzíková ${ }^{1}$, Mariana Strenitzerová ${ }^{2}$
}

\section{Strategické riadenie l'udských zdrojov}

Strategické riadenie l'udských zdrojov [1] je prístup k rozhodovaniu o zámeroch organizácie týkajúcich sa l'udí - podstatnej zložky podnikatel'skej stratégie organizácie. Jedná sa o vzájomné vzt’ahy medzi riadením l’udských zdrojov a strategickým riadením v organizácii. Strategické riadenie l’udských zdrojov sa týka celkového zamerania organizácie, pokial' ide o zabezpečenie jej ciel'ov pomocou a prostredníctvom l'udí. Pretože podl'a posledných analýz sú to l'udia, ktorí realizujú strategický plán, vrcholový manažment musí zobrat' tento kl'účový faktor úplne do úvahy pri vypracovávaní svojich podnikových stratégii. Z tohto hl'adiska je strategické riadenie l’udských zdrojov neoddelitel'nou súčast'ou týchto stratégii. Uvádza sa taktiež, že strategická schopnost' firmy - dosiahnut' trvalú konkurenčnú výhodu - závisí na schopnostiach jej zdrojov, a l'udia nepochybne tvoria hlavný zdroj.

Strategické riadenie l'udských zdrojov možno považovat' za prístup k riešeniu dlhodobých záležitostí týkajúcich sa l'udí a tvorí súčast' strategického úsilia manažmentu podniku. Zahŕňa makroorganizačné záležitosti týkajúce sa štruktúry a kultúry, efektívnosti a výkonnosti organizácie, prispôsobenia zdrojov budúcim potrebám a požiadavkám podniku a riadenia zmeny. Z celkového pohl'adu sa bude zameriavat' na všetky hlavné záležitosti týkajúce sa l'udí, ktoré ovplyvňujú, alebo môžu byt' ovplyvňované strategickými plánmi organizácie, a bude zabezpečovat' agendu zmien vyjadrujúcu zámery, ako tieto záležitosti zvládnut'.

Strategické riadenie l'udských zdrojov je previazané so strategickým riadením podniku, pramení v ňom, ale je zároveň jeho ústredným prúdom. Nástrojom strategického riadenia l'udských zdrojov je potom strategické (dlhodobé) personálne plánovanie. Problémy strategického riadenia l'udských zdrojov je nutné chápat' v kontexte s problémami podnikovej stratégie a podnikového strategického riadenia. Je tu určitá logická postupnost', ktorú nemožno opomenút'. Model strategického riadenia l'udských zdrojov je znázornený na obr. 1. [2].

\footnotetext{
${ }^{1}$ Mgr. Kamila Jandzíková, Slovenská pošta, a.s., Partizánska cesta 9, 97599 Banská Bystrica, Slovenská republika tel. 00421-048-433 92 06, fax 00421-048-411 52 13, e-mail: jandzikova.kamila@slposta.sk

${ }^{2}$ doc. Ing. Mariana Strenitzerová, PhD., Žilinská Univerzita v Žiline, Fakulta prevádzky a ekonomiky dopravy a spojov, Katedra spojov, Univerzitná 1, 01026 Žilina, Slovenská republika tel. 00421-041-5133 131, fax 00421-041-5655 615, e-mail: Mariana.Strenitzerova@fpedas.uniza.sk
} 
Obr. 1. Strategické potreby podniku a riadenie l’udských zdrojov

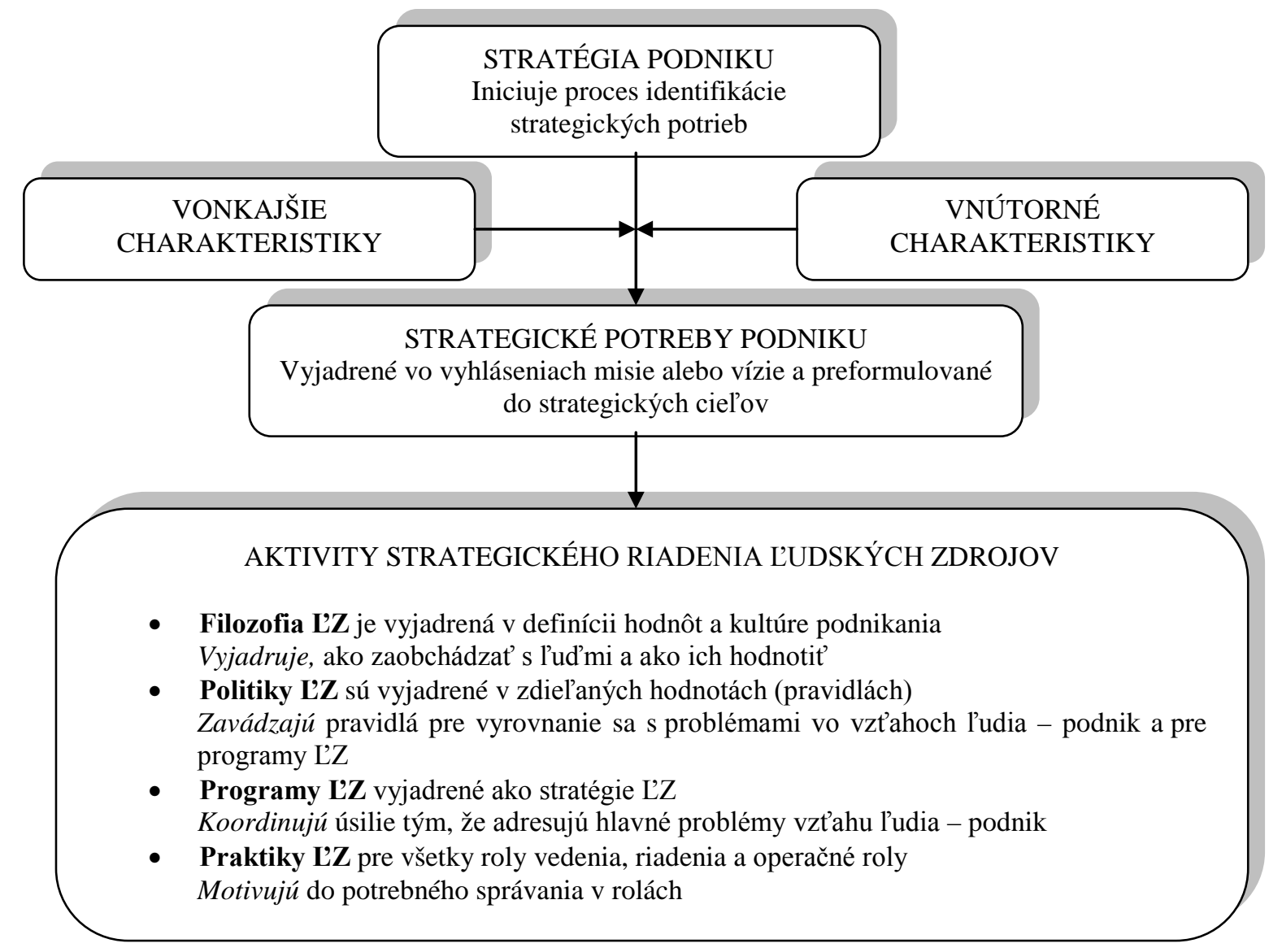
otázky:

Všeobecné podnikové strategické riadenie musí v prvom rade riešit’ nasledujúce

1. Akú podnikatel'skú filozofiu si chce podnik vytvorit', aké chce mat' poslanie a akú rolu si praje hrat' na trhu?

2. Akým pozitívnym a negatívnym vonkajším faktorom musí čelit??

3. Aké sú prednosti a nedostatky podniku?

4. Aké ciele chce podnik dosiahnut?

5. Ako chce tieto ciele dosiahnut?

Všetky tieto otázky v sebe implicitne zahŕňajú problematiku l'udských zdrojov a nemožno ich zodpovedat', pokial' l'udské zdroje nebudú brané do úvahy. Tie totiž determinujú do značnej miery formuláciu podnikovej filozofie, podnikového poslania i rolu podniku na trhu. Pozitívnym či negatívnym vonkajším faktorom spravidla býva populačný vývoj, teda reprodukcia pracovných zdrojov a pracovných síl, rozmiestnenie obyvatel'stva (osídlenie), jeho rezidenčná preferencia a priestorová mobilita a s tým všetkým súvisiaca situácia na trhu práce. Povaha práce v podniku, stávajúce množstvo a štruktúra (predovšetkým profesne-kvalifikačná) zamestnancov, ich pracovné správanie, produktivita práce, mobilita, flexibilita a pod. - to všetko môžu byt' prednosti alebo nedostatky podniku. A všetky tieto skutočnosti determinujú ciele, ktoré chce podnik dosiahnut', i cesty k ich dosiahnutiu.

Z predchádzajúcich otázok teda logicky plynú otázky, ktoré musí podnikové strategické riadenie l'udských zdrojov riešit' predovšetkým:

1. Akú mieru súladu medzi pracovnými miestami a zamestnancami chce podnik v budúcnosti dosiahnut? 
2. Aká je súčasná miera súladu a z nej vyplývajúca úroveň produktivity práce a osobného uspokojenia zamestnancov?

3. Aké zmeny v politike i v praktickej činnosti na úseku l'udských zdrojov sú nevyhnutné, aby bol dosiahnutý žiaduci súlad medzi pracovnými miestami a zamestnancami?

\section{V priebehu strategických úvah sa tieto otázky ešte konkretizujú:}

1. Kol'ko a aký druh zamestnancov bude podnik potrebovat'?

2. Aká ponuka pracovných síl sa v podniku i mimo neho perspektívne predpokladá?

3. Čo je potrebné urobit', aby bola pokrytá žiaduca perspektívna potreba zamestnancov $\mathrm{v}$ podniku?

Aby bolo možné dat' na všetky uvedené otázky spol'ahlivú odpoved', musí sa podnikové strategické riadenie dôkladne zaoberat' nielen vnútornými podmienkami podniku, ale predovšetkým podmienkami vonkajšími. Tie určujú mantinely, v ktorých sa môžu pohybovat' strategické úvahy a konieckoncov i riešenia bežných úloh personálnej práce. Sú to predovšetkým nasledujúce vonkajšie podmienky:

1. Populačný vývoj a jeho dopad na reprodukciu pracovných zdrojov a pracovných síl,

2. Vývoj trhu práce, predovšetkým vývoj vzt’ahu medzi ponukou pracovných síl a dopytom po nich, a to nielen čo do množstva, ale aj čo do štruktúry,

3. Zmeny techniky a technológie využívanej alebo využitel'nej v podniku,

4. Zmeny hodnotových orientácii l'udí, predovšetkým zmeny profesne-kvalifikačných orientácií, orientácií týkajúcich sa vzdelania, rodiny, sociálnych potrieb a pod.. Dôležité je hlavne rozpoznat' mieru stability obl'uby určitých povolaní, typov vzdelania, poprípade modelov rodiny a rodinných orientácií žien,

5. Priestorová mobilita obyvatel'stva, pracovných zdrojov a pracovných síl - vrátane medzištátnej mobility, prekážky stojace v ceste vol'nej mobility (administratívne, bytové, socio-psychologické a iné), migračná aktivita jednotlivých sídiel či regiónov a jej územná diferenciácia, rezidenčná orientácia (preferencia) l’udí (miera obl’uby bývania v rôznych typoch sídiel, napr. prít’ažlivost' vel'komiest či území vyznačujúcich sa určitou kvalitou životného prostredia),

6. Pracovná a sociálna legislatíva a politika zamestnanosti (štátna či lokálna), miera ich stability.

Je však potrebné brat' do úvahy i d'alšie vonkajšie podmienky, ako napr.:

7. Priebeh tzv. priemyslového cyklu, t.j. striedanie obdobia konjunktúry a depresie,

8. Možné zmeny v dopyte po výrobkoch či službách podniku (čo do množstva, tak čo do štruktúry), poprípade možné zmeny konkurenčného prostredia na trhu výrobkov a služieb, možné zmeny na trhu surovín a energií,

9. Zmeny v miere otvorenosti národnej ekonomiky, stabilitu politických pomerov a zákonov spoluvytvárajúcich d'alšie podmienky pre činnost' podniku atd'..

Mimoriadny význam má skúmanie väčšiny týchto podmienok v bezprostrednom okolí podniku, na území, na ktorom má trvalé bydlisko rozhodujúca čast' zamestnancov podniku, v žiadnom prípade však nemožno ignorovat' ani ostatné regióny štátu. Pracovná sila v krajinách s vyspelou trhovou ekonomikou sa vyznačuje vysokou priestorovou i pracovnou mobilitou a podniky tak nebývajú závislé len na pracovných zdrojoch nachádzajúcich sa v najbližšom okolí. U nás však zatial' dost' podstatne limituje priestorovú mobilitu pracovných síl nepriaznivá situácia $\mathrm{v}$ oblasti bývania, predovšetkým v mestách a v priemyslových aglomeráciách.

Pokial' ide o vnútorné podmienky, tak je potrebné zaoberat' sa tromi skupinami podmienok, ktoré súvisia s: 
1. organizáciou (vel'kost' podniku, organizačná štruktúra, priestorová štruktúra, technika a technológia, produkcia, personálna politika, kultúra a iné),

2. prácou (charakter a obsah, podnetnost' (zaujímavost'), rozmanitost', autonómia, obtiažnost', rizikovost', úroveň a formy organizácie práce, individuálny alebo tímový charakter a iné),

3. zamestnancami (počet, demografická, ekonomická, sociálna a priestorová štruktúra, ich znalosti a vedomosti, rozvojový potenciál, mobilita (fluktuácia), osobnost', hodnotové orientácie, očakávania, rodinné zázemie, bytové a iné životné podmienky a iné).

Ako vidno podnikové strategické riadenie l'udských zdrojov musí brat' do úvahy množstvo faktorov ovplyvňujúcich perspektívne formovanie a fungovanie podnikovej pracovnej sily a tým i podniku. Nutnost' komplexného prístupu k formulovaniu strategických personálnych ciel'ov a $\mathrm{k}$ vol'be metód používaných $\mathrm{k}$ dosiahnutiu týchto ciel'ov i nutnost' širokého odborného profilu personalistu je tým dostatočne preukázaná [3].

\section{Stratégia riadenia l’udských zdrojov v podmienkach Slovenskej pošty}

Platná stratégia l’udských zdrojov je upravená v rámci podnikovej stratégie a rozpracovaná $\mathrm{v}$ „Programe rozvoja l’udských zdrojov v Slovenskej pošte, a. s., do roku 2011“. V uvedenom programe rozvoja l’udských zdrojov sú definované ciele vychádzajúce zo strategických ciel'ov spoločnosti, nástroje, postupy a aktivity, ktoré vedú k ich naplneniu. Podmienkou realizácie programu je zohl'adnenie interných a externých vplyvov, ovplyvňujúcich jej úspešnost'.

Ciel'om je vybudovanie komplexného a efektívneho systému riadenia l'udských zdrojov $\mathrm{s}$ využitím vhodného personálneho informačného systému, a to $\mathrm{v}$ podnikovom prostredí, ktoré zabezpečí zvýšenie výkonnosti spoločnosti a podporí získanie a udržanie dobrého mena spoločnosti [4].

Stratégia l'udských zdrojov je zameraná na 7 oblastí, ktorými sú:

1. systém organizácie práce a personálneho manažmentu,

2. systém získavania a výberu zamestnancov,

3. systém adaptácie zamestnancov,

4. systém vzdelávania zamestnancov,

5. systém hodnotenia zamestnancov,

6. systém kariérneho rozvoja zamestnancov,

7. systém motivácie zamestnancov.

Systém organizácie práce a personálneho manažmentu je zameraný na efektívne využívanie a hospodárenie s l'udským kapitálom a participáciu vedúcich zamestnancov na riadení l'udských zdrojov. Medzi najvýznamnejšie aktivity patria:

- identifikácia možností optimalizácie personálneho manažmentu, manažmentu vzdelávania,

- aktualizovanie systému typových pozícií,

- optimalizovanie pracovných činností a postupov,

- zabezpečenie zmien organizačnej štruktúry pri rešpektovaní strategických zámerov,

- definovanie kl'účových zamestnancov,

- podporovanie pracovnej mobility zamestnancov,

- uplatňovanie pravidiel outplacement (systém poskytujúci podporu prepusteným zamestnancom),

- využívanie outsourcingu predovšetkým $\mathrm{v}$ činnostiach spoločnosti bezprostredne nesúvisiacich s core businessom. 
V oblasti získavania a výberu zamestnancov je stratégia zameraná na aktívne vyhl'adávanie perspektívnych zamestnancov hlavne na kl'účové pozície v spolupráci so školami, úradmi práce a personálnymi agentúrami a na efektívne aplikovanie absolventského programu.

V rámci systému adaptácie zamestnancov je stratégia orientovaná na zmenu tohto systému, najmä aktívnym zapojením tútorov.

Hlavným zameraním systému vzdelávania zamestnancov je prehlbovanie a rozširovanie vedomostí, zručností a schopností zamestnancov v záujme zvýšenia ich flexibility s možnost'ou využitia finančných zdrojov eurofondov. Nosnou aktivitou je cielená rekvalifikácia zamestnancov a adresnost' vzdelávania.

Pri systéme hodnotenia zamestnancov je hlavným ciel'om jeho prepojenie s ostatnými systémami riadenia l'udských zdrojov.

Kariérny rozvoj zamestnancov je zameraný na zabezpečenie rozvoja zamestnancov v zhode s vlastnými potrebami a možnost'ami, ako aj s potrebami a možnost'ami spoločnosti a vytvorenie databázy personálnych rezerv.

Oblast' motivácie zamestnancov je zameraná najmä na výkon zamestnanca, rast produktivity práce, na štruktúru priemernej mzdy, odmeňovanie klúčových zamestnancov, ale aj na zavedenie nových motivačných nástrojov v rámci systému zamestnaneckých výhod a nových nástrojov v oblasti starostlivosti zamestnancov.

Program rozvoja l'udských zdrojov sa dotkol aj firemnej kultúry, ktorej zmena mala dosiahnut', aby sa stala strategicky žiaducou. Za tým účelom bol už v roku 2006 na základe nezávislého auditu firemnej kultúry, zostavený Program zmeny firemnej kultúry vrátane akčného plánu zmeny firemnej kultúry, ktorého jednotlivé úlohy sú priebežne plnené.

Nevyhnutnou súčast'ou strategických dokumentov je poukázanie na rizikové faktory, ktorých existenciu a dopad je možné ovplyvnit', o. i. prijatím včasných a správnych opatrení a automatizáciou. Rizikovými faktormi voblasti l'udských zdrojov v podmienkach spoločnosti podl'a programu rozvoja l'udských zdrojov sú hlavne vysoká zamestnanost' ovplyvnená vysokým podielom fyzickej práce predovšetkým pri spracovaní zásielok, nízka automatizácia a mechanizácia, zložité technologické postupy, duplicita vykonávaných činností.

Najvýznamnejším strategickým zámerom v oblasti l’udských zdrojov po prechode od personálneho manažmentu k manažmentu l'udských zdrojov je dosiahnutie vrcholnej fázy vývoja l’udských zdrojov - l’udský kapitál.

\section{Aktivity v oblasti l'udských zdrojov realizované v nadväznosti na rozvojové zámery Slovenskej pošty}

V rámci rozvojových programov a stratégií l’udských zdrojov či už priamo alebo nepriamo dominoval jeden zo základných prvkov riadenia l’udských zdrojov, ktorým je plánovanie l'udských zdrojov a ich efektívne využívanie. Na začiatku roka 2006 bol do praxe zavedený nový nástroj „špecializovaný audit l’udských zdrojov“ využívajúci viacero metód ako sú bodová metóda, skálogramová metóda, selfmonitoring a empirické a dopadové štúdie.

Nový nástroj a jeho metódy umožňujú:

- plánovanie počtu zamestnancov v súčasnom aj budúcom období,

- optimalizáciu počtu zamestnancov,

- sledovanie výkonu zamestnancov s možnost'ou prepojenia na oblast' odmeňovania.

Za účelom skvalitnenia získavania zamestnancov bola vytvorená koncepcia náboru a výberu zamestnancov založená na nových prvkoch, metódach a efektívnejších postupoch. Najväčší význam v tejto oblasti malo zavedenie nových a efektívnejších prvkov, ktorými sú 
najmä spolupráca so vzdelávacími inštitúciami, účast' na burzách práce, odporúčania vlastných zamestnancov a zvýšenie podielu inzerátov prostredníctvom internetu.

Systém odmeňovania zamestnancov je nepretržite sledovaný úsekom l'udských zdrojov najmä prostredníctvom auditov, porovnávacej analýzy, analýzy prirodzených úbytkov v čiastke vyplatených miezd a meraním spokojnosti zamestnancov. Výstupy merania spokojnosti zamestnancov ukázali, že z hl'adiska dôležitosti motivačných faktorov najdôležitejšími faktormi pre zamestnancov sú priamy nadriadený, sociálne istoty a systém odmeňovania. $\mathrm{Z}$ monitoringov systému odmeňovania, úrovne produktivity práce a strategických ciel'ov spoločnosti vyplýva, že je potrebné v súčasných podmienkach, aj napriek novým trendom $\mathrm{v}$ tejto oblasti, venovat' neustálu pozornost' prepojeniu odmeňovania na výkon zamestnancov, podpore pracovnej mobility zamestnancov, prepojeniu výsledkov z aplikácie jednotlivých systémov a metód na odmeňovanie.

Za účelom skvalitňovania podmienok pre motivovanejší personál a tým aj zvýšenie kvality práce bol vytvorený motivačný program zameraný nielen na odmeňovanie zamestnancov, ale aj na:

- starostlivost' o zamestnancov,

- vzdelávanie zamestnancov,

- zamestnanecké výhody,

- zamestnanecké vzt’ahy a sociálny rozvoj.

Systém hodnotenia zamestnancov za účelom optimálneho využitia pracovného potenciálu zamestnancov spoločnosti na základe získaných informácií o ich pracovnom výkone, pracovnom správaní a schopnostiach je neustále analyzovaný a prispôsobovaný podmienkam spoločnosti.

Novým prvkom v oblasti vzdelávania zamestnancov je Katalóg vzdelávacích aktivít, z ktorého vedúci zamestnanci môžu vyberat' vzdelávacie aktivity vhodné pre zvýšenie schopností, zručností a vedomostí zamestnancov.

Významným prvkom a prínosom pre Slovenskú poštu je začlenenie sa zamestnanca do spoločnosti a miera jeho stotožnenia sa sfiremnou kultúrou. Dobrá firemná kultúra pomôže napíňat' ciele spoločnosti a zároveň aj prispievat' k naplneniu potrieb zamestnancov. Formálne definovanie sa začalo v roku 2006 po adaptácii všetkých zamestnancov na nové podmienky v prostredí akciovej spoločnosti. V roku 2008 bol vypracovaný návrh vyhlásenia a následne akčný plán.

Nevyhnutnou súčast'ou efektívnej práce personálneho manažmentu sú informačné systémy. Pokrok pre úsek l’udských zdrojov v tejto oblasti znamená nová verzia personálneho informačného systému a zavedenie d’alšich modulov, ktorými sú organizačná štruktúra, vzdelávanie zamestnancovo a uchádzači o zamestnanie.

Novým nástrojom k dosahovaniu ciel’ov spoločnosti, k zvýšeniu výkonnosti a konkurencieschopnosti spoločnosti v oblasti l’udských zdrojov je personálny controlling, ktorý môže pomôct' pri identifikácii prínosov riadenia l'udských zdrojov ako strategického nástroja riadenia.

Personálny controlling $\mathrm{v}$ užšom zmysle má kvantitatívny a operatívny charakter a hodnotí účinnost' a výstupy personálnych procesov. V širšom chápaní sleduje kvalitu riadenia l'udských zdrojov, jeho postupov a nástrojov. K riadeniu jednotlivých personálnych procesov potrebuje personálny controlling rôzne meracie veličiny a ukazovatele.

Vytváranie predpokladov pre zavedenie prvkov moderného riadenia l’udských zdrojov je spojené s konceptom „business partner“. Túto úlohu v súčasnom období plnia personálni controlleri. Business partner vytvára a spoluvytvára strategické riešenia firmy. Musí byt' schopný zodpovedat' na otázky smerovania a potenciálu l'udských zdrojov, napríklad: Aká je súčasná pozícia na trhu, aká je želaná pozícia v horizonte niekol'kých rokov? Akých máme 
momentálne l'udí vo firme a akých budeme potrebovat' pre naše plány do budúcnosti? Ktorí zamestnanci a prečo sú pre firmu kl'účoví a ako ich rozvíjat', koho máme „V zálohe“ ako náhradu za klúčových zamestnancov a manažérov a ako s nimi pracujeme? Sú poskytované benefity $\mathrm{v}$ súlade $\mathrm{s}$ trhom?

\section{Uplatnenie metodiky BSC v strategickom riadení l’udských zdrojov}

Strategický význam útvaru l’udských zdrojov býval v porovnaní s výrobou, logistikou, financiami a marketingom podceňovaný. $V$ očiach podnikového vedenia býval personálny útvar štábnou funkciou, ktorej hlavnou úlohou bolo „vybavovat' administratívne záležitosti okolo personálu“. To sa dnes postupne mení.

V mnohých podnikoch sa ako účinný nástroj strategického riadenia využíva Balanced Scorecard (BSC). Slovenská pošta sa pri koncipovaní novej stratégie riadenia l'udských zdrojov rozhodla vychádzat' práve z uplatnenia tejto metódy. BSC vnáša svetlo do 4 oblastí: financie, zákazníci, personál, procesy/systémy. Zapája do hry aj oblast’ l’udských zdrojov. BSC je založená na jednoducho meratel'ných veličinách, ktoré zrozumitel'ným spôsobom vypovedajú o všetkom podstatnom. Táto prednost' BSC môže byt' využitá i v samotnej oblasti l'udských zdrojov. Pomocou vhodne zvolených ukazovatel'ov môže byt' strategicky významná výkonnost' l'udských zdrojov preložená do zrozumitel'ných podnikatel'ských termínov.

\section{Obr. 2. Základné perspektívy BSC}

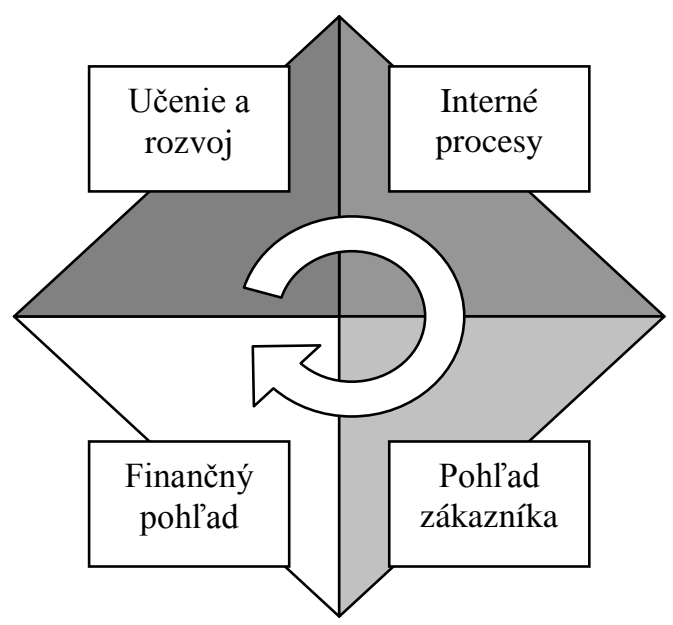

Pokial' má byt' metodika BSC uplatnená v oblasti l'udských zdrojov, je nutné stanovit' jasné strategické ciele pre oblast' l’udských zdrojov. Prvým krokom je zostavit' komplexnú stratégiu l'udských zdrojov odvodenú zo stratégie firmy. V nej musia byt' obsiahnuté dôsledky vyplývajúce z firemnej stratégie pre oblast' l'udských zdrojov a definované jednotlivé dielčie oblasti riadenia l'udských zdrojov. Na tejto báze sa potom stanovujú strategické ciele v každej zo štyroch dimenzií BSC: financie - zákazníci - personál - procesy/systémy. Pre tieto ciele sa potom stanovia zodpovedajúce meratel'né ukazovatele. Pre zaistenie naznačených dielčích ciel'ov sa následne zostavujú a realizujú súbory opatrení.

Postup nasadenia BSC v personálnom manažmente:

1. porozumenie prijatej stratégie l'udských zdrojov

2. určenie dôsledkov prijatej stratégie pre oblast' l'udských zdrojov

3. stanovenie strategických ciel'ov pre oblast' l'udských zdrojov

4. vypracovanie meratel’ných indikátorov pre hodnotenie strategických ciel'ov

5. návrh strategických programov (súborov opatrení) 


\section{Záver}

Zavedením BSC v riadení l’udských zdrojov je možné dosiahnut' napr. významný pokrok vo zvýšení atraktivity podniku na pracovnom trhu a taktiež v príprave personálu na trhovú liberalizáciu. Uplatnenie BSC v oblasti l'udských zdrojov je dlhodobý proces. Zložitost' procesu je daná jednak počtom použitých ukazovatel'ov a jednak nárokmi na vykazovanie a predkladanie správ o výsledkoch týchto ukazovatel'ov (reporting).

BSC umožňuje riadit' útvar l'udských zdrojov podl'a podnikatel'ských princípov a vyhodnocovat' jeho príspevok k úspešnosti celej firmy.

\section{Literatúra}

[1] ARMSTRONG, M.: Personální management. Praha, Grada Publishing, 1999

[2] STRENITZEROVÁ, M.- PONIŠČIAKOVÁ, O.: Diagnostika a manažment procesov v riadení l'udských zdrojov, Monografia, Žilinská univerzita v Žiline/EDISvydavatel'stvo ŽU, 2006, ISBN 80-8070-579-8, 135 s., 67 obr., 6 tab.

[3] GERRY JOHNSON, KEVAN SCHOLES: Cesty k úspěšnému podniku - stanovení cíle, techniky rozhodování. Computer Press, Praha, 2000

[4] Program rozvoja l’udských zdrojov v Slovenskej pošte, a.s., do roku 2011 